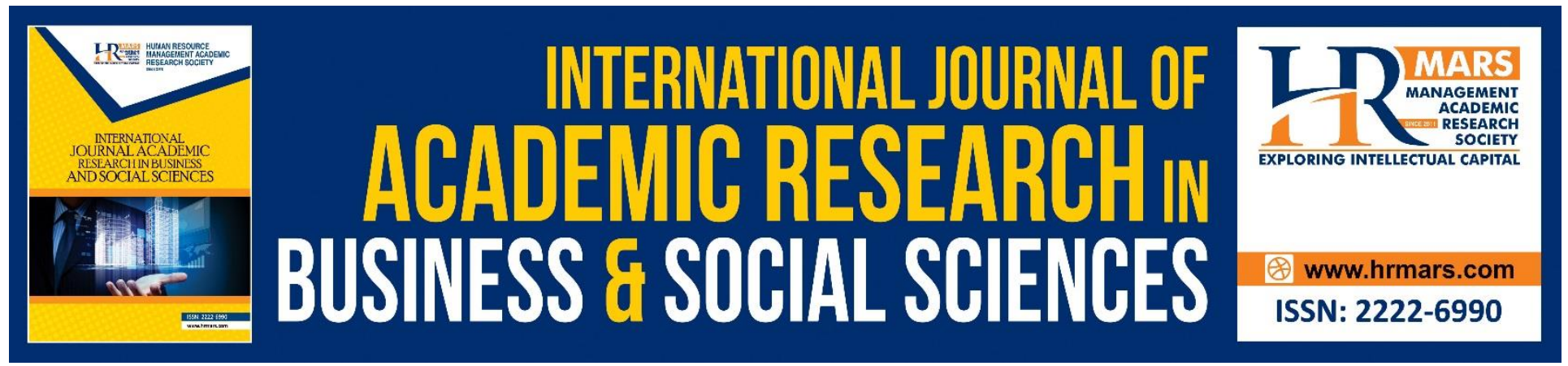

\title{
Leadership Style: Transformational and Employees' Job Satisfaction in Sektor Khidmat Pengurusan dan Pembangunan at Jabatan Pendidikan Negeri Johor
}

Noor Haty Nor Azam, Nur Elimtiaz Abidin, Gladys Sebi Entigar, Milfadzhilah Mohd Jamil, Nashrah Tali, Roziana Ahmed, Wan Nor Syazana Wan Hashim, Aida Nur Mohd Kodri, Mohd Azmil Mohd Yusof \& Norasyikin Ibrahim

To Link this Article: http://dx.doi.org/10.6007/IJARBSS/v8-i7/4398

DOI: $\quad 10.6007 /$ IJARBSS/v8-i7/4398

Received: 20 May 2018, Revised: 23 June 2018, Accepted: 29 June 2018

Published Online: 17 July 2018

In-Text Citation: (Azam et al., 2018)

To Cite this Article: Azam, N. H. N., Abidin, N. E., Entigar, G. S., Jamil, M. M., Nashrah Tali, R. A., Hashim, W. N. S. W., ... Ibrahim, N. (2018). Leadership Style: Transformational and Employees' Job Satisfaction in Sektor Khidmat Pengurusan dan Pembangunan at Jabatan Pendidikan Negeri Johor. International Journal of Academic Research in Business and Social Sciences, 8(7), 465-473.

Copyright: (C) 2018 The Author(s)

Published by Human Resource Management Academic Research Society (www.hrmars.com)

This article is published under the Creative Commons Attribution (CC BY 4.0) license. Anyone may reproduce, distribute, translate and create derivative works of this article (for both commercial and non-commercial purposes), subject to full attribution to the original publication and authors. The full terms of this license may be seen

at: http://creativecommons.org/licences/by/4.0/legalcode

Vol. 8, No. 7, July 2018, Pg. 465 - 473

Full Terms \& Conditions of access and use can be found at http://hrmars.com/index.php/pages/detail/publication-ethics 


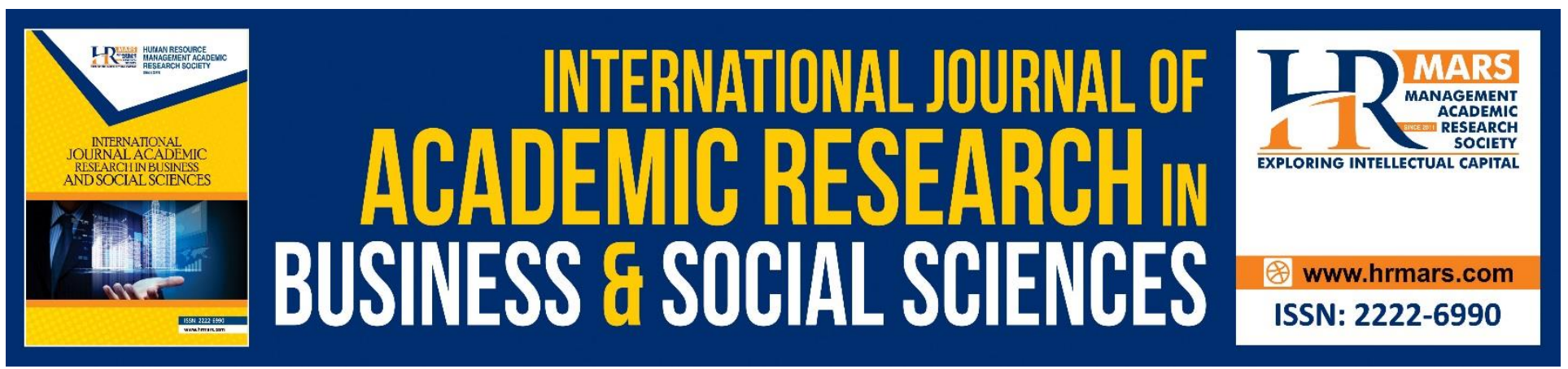

\title{
Leadership Style: Transformational and Employees' Job Satisfaction in Sektor Khidmat Pengurusan dan Pembangunan at Jabatan Pendidikan Negeri Johor
}

\author{
${ }^{1}$ Noor Haty Nor Azam, ${ }^{2}$ Nur Elimtiaz Abidin, ${ }^{3}$ Gladys Sebi Entigar, \\ ${ }^{4}$ Milfadzhilah Mohd Jamil, ${ }^{5}$ Nashrah Tali, ${ }^{6}$ Roziana Ahmed, ${ }^{7}$ Wan Nor \\ Syazana Wan Hashim, ${ }^{8}$ Aida Nur Mohd Kodri, ${ }^{9}$ Mohd Azmil Mohd \\ Yusof $\&{ }^{10}$ Norasyikin Ibrahim
}

Faculty of Business Management, Universiti Teknologi MARA Melaka, Malaysia

\begin{abstract}
To achieve job satisfaction among employees is the focal point of most organizations. It is because the issue of employee's job satisfaction has been long debated due to its subjectivity. Therefore, an attempt has been made to identify the relationship between transformational leadership style and employees' job satisfaction at Jabatan Pendidikan Negeri Johor. The respondents were collected from 97 respondents using questionnaire survey. The respondents will be selected using probability stratified sampling technique and was analyzed using correlation analysis. The results indicate that transformational leadership style is significant to predict employees' job satisfaction.
\end{abstract}

Keywords: Job satisfaction, Transformational leadership style

\section{Introduction}

Nowadays, the success of organization depends on employee's satisfaction towards job. Job satisfaction is vital in an organization because it helps to achieve organization's goals and objectives. If employees satisfied with the job, it can improve job performance as well as organization's performance.

Therefore, organization can achieve its competitive advantages among competitors. One of the factors that influence job satisfaction is leadership style. Avolio, Bass and Jung (1997) identified leaderships into two categories; transformational and transactional.

However, this study was focused on transformational leadership style. This is because the transformational style is more acceptable, and this kind of leaders tend to have dedicated and satisfied followers (Alisa, Dzevad, Zijada \& Jasmin, 2014). This is supported by Robbins, Odendaal and Roodt (2003) leader plays an important role to increase job satisfaction where the leader has an 
INTERNATIONAL JOURNAL OF ACADEMIC RESEARCH IN BUSINESS AND SOCIAL SCIENCES

Vol. 8, No. 7, July 2018, E-ISSN: 2222-6990 @ 2018 HRMARS

ability to provide emotional and technical support to employees and directly impact the way how task has been done.

However, lack of support from the leader leads to dissatisfied employees in an organization. The employees might feel inadequate with what had been received in terms of motivations, freedom, benefits and so on.

The findings from this study might contribute for establish theory. It is because, this study looks at the important of transformational style to job satisfaction. The organization could use the findings to help improving job satisfaction among employees.

Hence, this study was conducted to identify the relationship between transformational leadership style and employees' job satisfaction in Sektor Khidmat Pengurusan dan Pembangunan, Jabatan Pendidikan Negeri Johor.

A. Research Objective

To identify the relationship between transformational leadership style and employees' job satisfaction in Sektor Khidmat Pengurusan dan Pembangunan, Jabatan Pendidikan Negeri Johor.

B. Research Question

Is there any relationship between transformational leadership style and employees' job satisfaction in Sektor Khidmat Pengurusan dan Pembangunan, Jabatan Pendidikan Negeri Johor?

C. Hypothesis

$\mathrm{H} 1$ There is a significant relationship between transformational leadership style and employees' job satisfaction in Sektor Khidmat Pengurusan dan Pembangunan, Jabatan Pendidikan Negeri Johor.

\section{Literature Review}

Job Satisfaction: Steven and McShane (2004) stated job satisfaction as the individual's evaluation of work in terms of the context and content of the work. Hanaysha, Khawaja, Nik Kamariah, Fosa, Muhd Yahya and Ahmad Sazali (2012) the elements of job satisfaction includes the job itself, the relationship in an organization, management beliefs, future opportunity, work environment and compensation.

Therefore, if all the elements are fulfilled by the employer, job satisfaction will be increased. This is because, when employees found the job is suitable and the superior motivates to express freedom, the employees will be happy to finish the task given. This is supported by Parvin and Kabir (2011) the workers generate job satisfaction when the workers happy with the job.

Leadership: Leadership defined as the approaches adopted by superiors in everyday interaction with employees. It consists of many elements that can affects employees' emotions, performance and behavior (Lok \& Crawford, 2004). Robbins (2000) defined leadership as the capabilities to influence employees towards the achievement of organizational objectives and goals.

Transformational leadership: The transformational leadership style was stressed in this study. This is because transformational leaders tend to create a working environment with satisfied and motivated employees (Bass and Riggio, 2008). This is supported by Northouse (2010) leaders who possessed transformational leadership style will motivate the followers and give more work outside the capabilities of an employees. 
INTERNATIONAL JOURNAL OF ACADEMIC RESEARCH IN BUSINESS AND SOCIAL SCIENCES

Vol. 8, No. 7, July 2018, E-ISSN: 2222-6990 (C) 2018 HRMARS

Bass and Riggio (2008) identified four behaviors that represents transformational leadership;

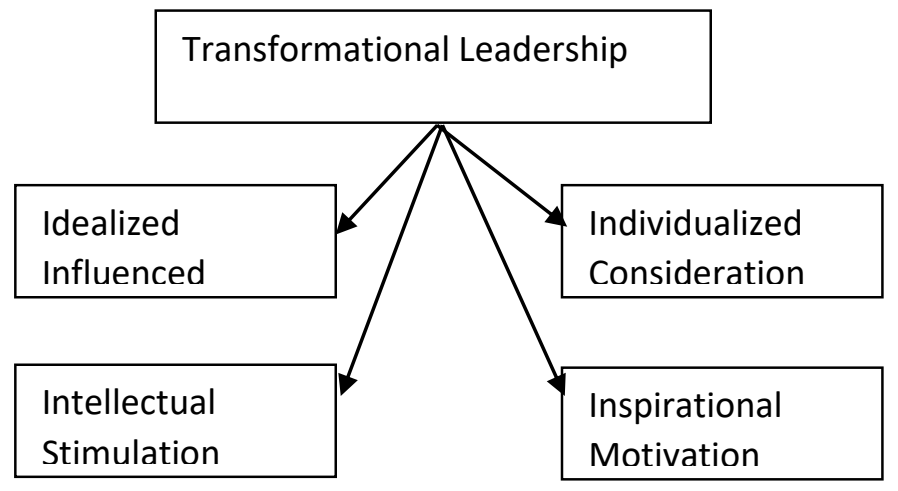

Figure 1: Transformational Leadership Behaviors

1. Idealized influenced (charisma) - strong emotions from followers and latter acts as a strong role model.

2. Individualized consideration - includes provisions of support, encouragement, coaching, advice and feedback for the use in the followers' personal development.

3. Intellectual stimulation - increase awareness of problems and influences followers to view problems from a new point of view.

4. Inspirational motivation - includes the development and communication of an appealing vision.

Hence, transformational leadership is significant related with job satisfaction (Manning, 2002). In addition, transformational kind of leadership having more positive effect on job satisfaction rather than transactional (Awamleh \& Al-Dmour, 2004). This is the reason this study is focused on transformational leadership style.

\section{Framework}

\section{INDEPENDENT VARIABLE DEPENDENT VARIABLE}

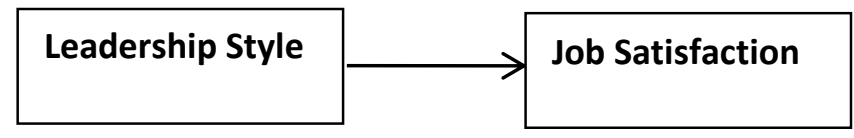

(Avolio, Bass \& Jung, 1997) (Spector, 1997)

Figure 2: Transformational Leadership Style and Job Satisfaction among employees in SKPP, Jabatan Pendidikan Negeri Johor.

The framework of this study consists independent variables (leadership style; transformational) and job satisfaction. The leadership style was adopted from Avolio, Bass and Jung (1997) and job satisfaction adopted from Spector (1997). 
INTERNATIONAL JOURNAL OF ACADEMIC RESEARCH IN BUSINESS AND SOCIAL SCIENCES Vol. 8, No. 7, July 2018, E-ISSN: 2222-6990 @ 2018 HRMARS

\section{Research Methodology}

Research Design: According to Salkind (2013), research design is the method and structure of an investigation to conduct data collection and analysis. The type of this research is known as correlational research. According to Sekaran and Bougie (2010) correlational research is conducted when the researcher wants to describe the important variables related with the problem. Besides, this study will be conducted to identify the relationship between transformational leadership style and job satisfaction on the established relationship.

Sampling Technique: The sampling technique that was applied in this study is cluster sampling technique.

Population and Sample: According to Salkind (2013), population is the entire of some group. According to Sekaran and Bougie (2010), population is defined as entire group of people the researchers want to investigate. The population for this study is 130 employees from Sektor Khidmat Pengurusan dan Pembangunan, Jabatan Pendidikan Negeri Selangor. The sample size based on table of Krejcie and Morgan (1970) as adopted by Sekaran and Bougie (2010). Krejcie and Morgan (1970) greatly simplified size decision by providing table that ensures a good decision model. Thus, the sample size for this study is 97 from the population of 130 .

Unit of Analysis: The unit of analysis used in this study is an individual comprises of employees in Sektor Khidmat Pengurusan dan Perkhidmatan, Jabatan Pendidikan Negeri Johor.

Sampling Frame: Garson (2012) stated sampling frame is a list of ultimate in population such as people, household, organization, or unit of analysis. For this study, the list name of employees was retrieved from Sektor Khidmat Pengurusan dan Perkhidmatan, Jabatan Pendidikan Negeri Johor.

Survey Instruments: The respondents are required to answer the three sections. The questionnaire was divided into three sections, Section A, Section B and Section $C$.

Section $A$ - This section asked and identifies the transformational leadership style from Multifactor Leadership Questionnaires (MLQ).

Section B - This section identifies the employees' job satisfaction. In this section, the items were adopted from Spector (1997).

Section $\mathbf{C}$-. This section classifieds the respondents according to the demographic profiles such as gender, age, marital status, professional academic qualification and working experience.

Measurement of Variables: The transformational leadership style and job satisfaction was measured by statement using five (5) points of Likert Scales: The five (5) points are as stated below:

1 = Strongly Disagree

2 = Disagree

$3=$ Neutral

4 = Agree

5 = Strongly Agree

Validity of Instrument: Zamalia (2009) stated validity is the ability of a scale to measure what needs to be measured. For this study, the validity of instruments was tested for criterion-related validity because to predict dependent variable, the independent variable was measured. 
INTERNATIONAL JOURNAL OF ACADEMIC RESEARCH IN BUSINESS AND SOCIAL SCIENCES Vol. 8, No. 7, July 2018, E-ISSN: 2222-6990 @ 2018 HRMARS

\begin{tabular}{|l|l|l|l|}
\hline \multirow{2}{*}{$\begin{array}{l}\text { No. } \\
\text { of } \\
\text { Item } \\
\text { s }\end{array}$} & RELIABILITY ANALYSIS & \multicolumn{3}{|l|}{ Pilot } \\
\cline { 2 - 4 } & $\begin{array}{l}\text { Study } \\
(\boldsymbol{n}=\mathbf{3 0} \\
)\end{array}$ & $\begin{array}{l}\text { Actual } \\
\text { Study } \\
(\boldsymbol{n}=\mathbf{9 7})\end{array}$ \\
\hline $\begin{array}{l}\text { IV(1 } \\
\text { 2) }\end{array}$ & $\begin{array}{l}\text { Transformational } \\
\text { Leadership Style }\end{array}$ & .852 & .936 \\
\hline $\begin{array}{l}\text { DV(3 } \\
\text { 0) }\end{array}$ & Job Satisfaction & .686 & .893 \\
\hline
\end{tabular}

Data Collection Procedures: The questionnaires were distributed to employees in Sektor Khidmat Pengurusan dan Pembangunan, Jabatan Pendidikan Negeri Johor. The respondents were given two weeks to return a complete questionnaire.

Reliability Analysis: According to Zamalia Mahmud (2009), reliability refers to the degree the measures of question are free from errors and lead to consistent results. In addition, reliability also seeks the understanding of questions from respondents. Therefore, in checking the reliability of the instruments, a pilot test was conducted to see whether the questionnaire is reliable or not. According to Sekaran (2010), the value of alpha level more than 0.60 will result in the instrument being reliable for the research study purposes. The pilot test for this study was conducted at the Jabatan Pendidikan Negeri Johor among 30 respondents to check the reliability. Besides, the reliability for actual study also was analyzed using SPSS. The results shown below:

Table 1: Reliability study for IV and DV

The results shown Cronbach' Alpha for both independent and dependent variables that consists of transformational leadership style and job satisfaction more than .60. In pilot study, Cronbach' Alpha for independent variable is .852 while for actual study the result shown .936 for transformational leadership style. In addition, for dependent variable, Cronbach' Alpha for pilot study is .686 and for actual study is .893. Hence, all the items are accepted and reliable for pilot study and actual study. Data Analysis: The data was analysed using Statistical Package for Social Sciences (SPSS). Analysis that was used in this study is Descriptive Statistic and Correlation Analysis. Then, the data were tabled and interpreted to come out with the findings.

\section{Findings}

The study was carried out at Jabatan Pendidikan Negeri Johor specifically among employees in Sektor Khidmat Pengurusan dan Pembangunan. The respondents for this study is 97 respondents from the population of 130.

In addition, the respondents for this study were given about two weeks to answer and return the questionnaires. The response rate for this study is 100 percent as 97 questionnaires were returned.

\section{Demographic Profiles of Respondents}

Demographic profiles of respondents consist of age, working experience, academic qualification, and age. Range of age for respondents in this study is 20 until 40 years old. 
INTERNATIONAL JOURNAL OF ACADEMIC RESEARCH IN BUSINESS AND SOCIAL SCIENCES

Vol. 8, No. 7, July 2018, E-ISSN: 2222-6990 @ 2018 HRMARS

In addition, from 97 respondents, 77 of respondents are females and 20 males. Most of the respondents possessed Diploma and bachelor's Degree for the academic qualification.

Mean and Standard Deviation

\begin{tabular}{|l|l|l|l|}
\hline Variables & $\mathbf{N}$ & Mean & $\begin{array}{l}\text { Standard } \\
\text { Deviation }\end{array}$ \\
\hline $\begin{array}{l}\text { IV } \\
\text { (Transformational } \\
\text { Leadership) }\end{array}$ & 97 & 3.4862 & .56113 \\
\hline $\begin{array}{l}\text { DV } \\
\text { (Job Satisfaction) }\end{array}$ & 97 & 3.4898 & .52135 \\
\hline
\end{tabular}

Table 2: Mean and Standard Deviation for Independent Variables and Dependent Variables.

Table 2 indicates the mean and standard deviation for transformational leadership and job satisfaction. For transformational leadership is $(M=3.4862$ and $S D=.56113)$ and dependent variables is $(M=3.4898$ and $S D=.52135)$ for 97 of respondents.

\begin{tabular}{|l|l|l|}
\hline \multirow{2}{*}{} & \multicolumn{2}{|l|}{ CORRELATION ANALYSIS } \\
\cline { 2 - 3 } & Variables & $\boldsymbol{R}$ value \\
\hline \multirow{2}{*}{ IV } & $\begin{array}{l}\text { Transformational } \\
\text { Leadership Style }\end{array}$ & .588** \\
\hline DV & Job Satisfaction & \\
\hline
\end{tabular}

\section{Correlation Analysis}

To answer the Research Question, the data were analyzed using SPSS (Statistical Package for Social Science) using correlation analysis. This test is important to determine the degree of coefficient between two variables. The results shown below:

**Correlation is significant at the level 0.01 (2 tailed)

Table 3: Correlation analysis for variables

Table 3 presents the relationship between transformational leadership style and job satisfaction. The analysis for correlation was conducted by using Pearson product-moment correlation coefficient. From the above table, transformational leadership style was correlated with job satisfaction $(r=.588$, $\mathrm{p}<.01)$. It indicates that employees want the leader with transformational leadership style because this kind of leader allowed employees to have autonomy or freedom in accomplish the task. This kind of leader also motivates and helps employees when needed. This is supported by Bushra, Usman and Naveed (2011) transformational leadership had a positive impact on general job satisfaction and indicating the employee's preferences for this leadership style. Therefore, hypothesis (H1) for this study is accepted. 
INTERNATIONAL JOURNAL OF ACADEMIC RESEARCH IN BUSINESS AND SOCIAL SCIENCES

Vol. 8, No. 7, July 2018, E-ISSN: 2222-6990 @ 2018 HRMARS

\section{Conclusions}

In conclusion, the result from this study is significant. In addition, the result supports main objective of this study to determine the relationship between transformational leadership style and employees' job satisfaction. Finding from this study shown that transformational leadership has a relationship with employees' job satisfaction. Therefore, leadership style influences the ways of employees react toward the job given and indirectly will improve the job satisfaction.

\section{References}

Awamleh, R. and Al-Dmour, H. (2004). The impact of transformational leadership on job satisfaction and self-perceived performance of banking employees: the case of jordan. International Business and Economic Research Journal, 3, 29-42.

Alisa M., Dzevad S., Zijada R. and Jasmin J. (2014). Transformational leadership and employee satisfaction, Econview, 259-270.

Avolio B. J., Bass B. M., and Jung D. I. (1997). Replicated confirmatory factor analyses of the multifactor leadership questionnaire.

Bushra F., Usman A., and Naveed A. (2011). Effect of transformational leadership on employees' job satisfaction and organizational commitment in banking sector of lahore. International Journal of Business and Social Science, 2(18), 261-267.

Hanaysha J. R. M., Khawaja K., Nik Kamariah N. M., Fosa S., Muhd Yahya A. R. and Z. Ahmad Sazali. (2012). Transformational leadership and job satisfaction. American Journal of Economics, 145-148.

Krejcie, R. V. and Morgan, D. W. (1970). Determining sample size for research activities. Educational and Psychological Measurement, 20, 607-610.

Lok P. and Crawford J. (2004). The effect of organizational culture and leadership style on job satisfaction and organizational commitment: A cross-national comparison. The Journal of Management Development, 23(4), 321-338.

Manning T. T. (2002). Gender, managerial level, transformational leadership and work satisfaction. Women in Management Review,17(5), 207-216.

Northouse P. G. (2010). Leadership, theory and practice. (6 $6^{\text {th }}$ ed). Sage: Thousand Oaks.

Parvin M. M. and Kabir N. (2011). Factors affecting employees job satisfaction of pharmaceutical sector. Australian Journal of Business and Management Research, 1(9), 113-123.

Robbins S. P. (2000). Organizational behavior: Concepts, controversies and applications. Englewood Cliffs: Prentice-Hall. 
INTERNATIONAL JOURNAL OF ACADEMIC RESEARCH IN BUSINESS AND SOCIAL SCIENCES

Vol. 8, No. 7, July 2018, E-ISSN: 2222-6990 @ 2018 HRMARS

Robbins, S.P., Odendaal, A., and Roodt, G. (2003). Organizational behavior, Global and Southern African Perspectives. ( $9^{\text {th }}$ ed). Cape Town: Pearson Education.

Salkind N. (2008). Exploring Research. $\left(8^{\text {th }}\right.$ ed). Pearson New International Edition.

Spector P. E. (1997). Job satisfaction: application, assessment, cause and consequences. Thousand Oaks. CA: Sage.

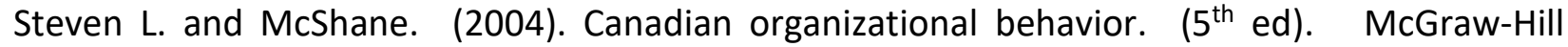
Ryerson, Toronto.

Mahmud, Z. (2009). Handbook of research methodology: a simplified version, University Publication Centre (UPENA). 